Моделюванням FlowSimulation/SolidWorks отримані параметричні поля течії бурового розчину в об'єкті дослідження - силовій секції гвинтового вибійного двигуна (ГВД). Предмет дослідження - характеристики турбулентності потоку поблизу точок дотику «ротор-статор» та між ними. Друга ділянка характерна розвиненою турбулентністю, дисипацією енергіi потоку, пошкодженнями статора твердою фазою розчину, що підтвердили ендоскопічні обстеження. Моделі дочільно використати при гідравлічних розрахунках ГВД

Ключові слова: гвинтовий вибійний двигун, пара «ротор-статор», буровий розчин, моделювання, параметричні поля

$\square$

Моделированием FlowSimulation/SolidWorks получены параметрические поля течения бурового раствора в оббекте исследования - силовой секции винтового забойного двигателя (ВЗД). Предмет исследования - характерристики турбулентности потока вблизи точек соприкосновения «ротор-статор» и между ними. Второй участок характерен развитой турбулентностью, Әиссипацией энергии потока, повреждениями статора твердой фазой раствора, что подтверждено эндоскопическими обследованиями. Модели целесообразно использовать при гидравлических расчетах ГВД

Ключевые слова: винтовой забойный двигатель, пара «ротор-статор , буровой раствор, моделирование, параметрические поля
UDC 622.226

DOI: $10.15587 / 1729-4061.2018 .126230$

\title{
EXAMINING THE CURRENT OF DRILLING MUD IN A POWER SECTION OF THE SCREW DOWN-HOLE MOTOR
}

\author{
V. B i le t s k y \\ Doctor of Technical Sciences, Professor* \\ E-mail: ukcdb@i.ua \\ V. V i t r y k \\ PhD, General Director** \\ $\mathbf{Y}$. M i s h c h u k \\ Process Engineer of technological department** \\ M. F y k \\ $\mathrm{PhD}$, Associate Professor* \\ A. D z h u s \\ Doctor of Technical Sciences, Professor *** \\ Y u. Kovalch u k \\ $\mathrm{PhD}$, Associate Professor \\ Department of Chemistry
}

Kyiv National University of Construction and Architecture Povitroflotsky ave., 31, Kyiv, Ukraine, 03037

T. Ro ma n y s h y $\mathbf{n}$ $\mathrm{PhD}$, Associate Professor $* * *$

A. $\mathbf{Y u r} \mathbf{~ y ~} \mathbf{h}$

$\mathrm{PhD}$, Associate Professor***

*Department of oil, gas and condensate extraction National Technical University «Kharkiv Polytechnic Institute» Kyrpychova str., 2, Kharkiv, Ukraine, 61002 **BUROVA TEKHNIKA, Research and Technical Enterprise, LTD Lesi Ukrainki blvd., 34, Kyiv, Ukraine, 36011 $* * *$ Department of drilling oil and gas wells Ivano-Frankivsk National Technical University of Oil and Gas Karpatska str., 15, Ivano-Frankivsk, Ukraine, 76019

\section{Introduction}

Screw down-hole motors (SDM) that are characterized by the relatively small specific metal consumption and the simplicity of design have been widely used at present for drilling horizontal, obliquely-directed, and vertical oil and gas wells. In addition, they are also applied when passing degasification wells in the complexes of methane extraction at coal deposits, post-exploration of mine fields of caustobiolith, development of thin off-balance oil reservoirs.

The basic elements of SDM are a spindle section, a section of curvature (a tilt angle adjuster), a power section (stator and rotor), a rotor catcher (a catcher of the rotor in case of an accident), reverse and circulation valves; the power section is the only element responsible for torque. When pumping drilling mud through a power section, it presses on the rotor, causing it to rotate. The stator is a casing in the form of a pipe or a profiled pipe whose internal covering is made from elastomers, which are the polymers with high elastic properties in a broad temperature range (for example, abrasion resistant rubber, rubbers). Consequently, the rotor and the rubberized stator (Fig. 1) are the most responsible units of SDM upon which the overall efficiency and operability of a screw down-hole motor depends. A SDM rotor has a special profile with a preset step of the screw line. The split ratio of the working bodies section is determined by the ratio of the number of rotor and stator teeth $Z_{\mathrm{r}}: Z_{\text {st }}$ in contemporary engines it is from 1:2 to $9: 10$. In the process of operation the elastomeric stator covering accepts cyclically alternating loads, reactive moment and radial forces. The rotor and stator are exposed to chemical and mechanical effects from drilling mud. Mechanical 
action of the components of drilling mud is caused by its speed and turbulent pulsations. The character of damage to the stator and rotor implies the detachment, cracks, cavities, chemical corrosion (Fig. 1).

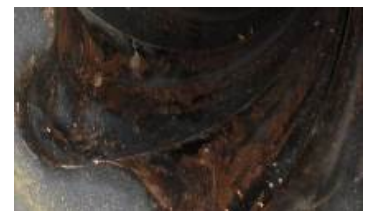

$a$

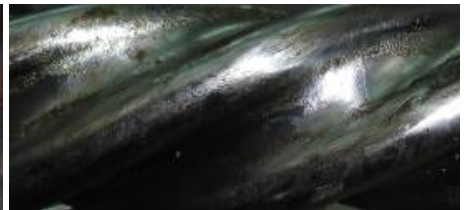

$b$
Fig. 1. Example of damage at the surface of: $a$ - stator; $b$ - rotor

There are following operational advantages of screw down-hole motors:

- optimal kinematic characteristics that ensure effective work of bits;

- minimum axial dimensions that allow using SDM when drilling obliquely-directed and horizontal wells, auxiliary wellbores;

- simple design and reparability.

At the same time, SDM has a major drawback - fast wear of the force section, which is the focus of attention of researchers to this object [1].

In the practice of SDM operation during drilling of the well, the instability of its work is often registered, namely the alternating modes from optimal to braking, stop of the engine. This is due to the heterogeneity of rocks, their different strength. In addition, extreme brake mode results in additional hydraulic losses that lead to a decrease in the energy characteristics of SDM [2].

Given the specific severe working conditions, it is appropriate, during hydraulic calculations of the screw down-hole motor, when choosing the rational mode of its operation, to take into consideration the parametric fields of the flow of drilling mud. Specifically, parametric fields of turbulence, which predetermine the action of a solid phase on the working surfaces of the stator and rotor and their wear.

\section{Literature review and problem statement}

Authors of paper [1] modelled the stressed-strained state of stator during operation of SDM by using the method of finite elements (SOLID92). It was established that the maximum contact pressure of $0.78 \mathrm{MPa}$ occurs at the place of contact between a stator slot and a rotor tooth.

Study [3] discovered the phenomenon of self-heating of a rubber covering to $123{ }^{\circ} \mathrm{C}$, which is caused by a cyclic loading during rotor rotation in the stator rubber covering. Thermal effect causes the loss of rubber's elastic properties, development of cracks and breaking the rubber covering.

Modeling of the heating of the stator due to the phenomenon of hysteresis in an elastomer was also performed in paper [4]. Model predictions are compared to empirical data; their convergence is established. In addition, the authors also consider a comparative study to different elastomers in the same power region. Model prediction and a monitoring system can be applied to obtain the optimal parameters of drilling, specifically for performance and reliability.

Authors of paper [5], using a method of computer simulation, determined the maximum permissible diametral den- sity of the worn operating parts of SDM. They established the critical value of wear, exceeding which results in the violation of tightness of working chambers with a decrease in the engine efficiency, performance of the machine is reduced.

Authors of [6] performed experimental analysis to determine basic factors that caused failures of the rotors of SDM employing a specialized test. It was established that these factors were the wear of the rotor surface due to solid particles and a salt additive to drilling mud. Similar results were obtained by authors of [7] who experimentally demonstrated that the type of drilling fluids and the temperature significantly affect the wear of SDM elastomers.

The drilling companies TOV "Gazprom drilling" (Russia) and "KCA Deutag" (international service company in the field of oil and gas extraction, headquartered in Aberdeen, United Kingdom) reported from 5 to 12 accidents over one year, related to SDM, which required long-term renovation work at the well, or even led to the complete closure of the well. In this case, approximately $50 \%$ of all failures are due to the wear of a rotor-stator pair in the force section.

Paper [9] points out that it is important, when designing new hydraulic drives, to eliminate vibration of the rotor and to reduce dimensions of the engine. In this case, there are two main ways to further improve hydraulic drives: modernization of contemporary screw motors and development of the new ones. It is proposed to apply a hybrid hydraulic system, which combines the best characteristics of a screw motor and a roller blade motor. The hybrid enables speed from 240 to $450 \mathrm{~min}^{-1}$. The main area of application of a hybrid hydraulic motor is the horizontal drilling of oil and gas deposits.

In paper [10], authors examined stator resource of the screw engine, which depends on many factors, specifically structural (design, materials) and well operating conditions. An important task, in the author's opinion, is the prediction of various structural and operating parameters on the deformation state and thermal effects in elastomer. The author established effect on the operational condition of the stator that is exerted by such parameters as design of the rotor/stator, temperature of a well, drilling fluid parameters, elastomer properties of the stator, speed of the engine, and differential pressure of the engine. A non-linear finite element analysis is applied in order to conduct thermal and structural analysis at the stator elastomer.

Authors of paper [11], employing the module Flow Simulation from the programming environment SolidWorks, investigated the work of the screw down-hole motor Wenzel Downhole Tools FD-M7-002 for drilling rigs under conditions of exploration of the Gnidintsy oil and gas condensate field. The authors obtained parametric fields - a field of velocity, temperature, and pressure of drilling mud in the working pair "rotor-stator". The derived SDM models are recommended for application in the hydraulic and thermodynamic calculations of a screw down-hole motor.

In order to estimate stable and reliable functioning of SDM, it is necessary to examine work of the screw downhole motor, specifically, to obtain the models of turbulence field of drilling mud in the working space of the power section. This issue has remained unexplored up to now.

The above studies lack the data, in the context of general problems in the operation of SDM, regarding the flow of drilling mud in the power section, specifically its turbulent pulsations and the related dissipation of energy and the damage to stator due to solid particles of the drilling mud. 


\section{The aim and objectives of the study}

The aim of present study is to determine patterns in the process of turbulent flow of drilling mud in the working space of a power section of the screw down-hole motor and its relation to the damage of the working surface of a SDM stator.

To accomplish the aim, the following tasks have been set:

- to construct models of the parametric field of turbulent flow of drilling mud in the SDM power section, of pressure field, of vorticity field, of turbulent time scale field, of the field of turbulence scale of drilling mud;

- to perform endoscopic examination of the SDM stator surface for detecting a damage (wear) of the working surface.

\section{Materials and methods used to study a power section of the screw down-hole motor}

\section{1. Examined materials and equipment used in the} experiment

We modeled a power section of the screw down-hole motor manufactured by Wenzel Downhole Tools (Canada) with a diameter of $171 \mathrm{~mm}$.

Drilling mud parameters: density is $1,100 \mathrm{~kg} / \mathrm{m}^{3}$, dynamic viscosity is $0.02 \mathrm{~Pa} \cdot \mathrm{s}$, specific heat capacity is $4.2 \mathrm{~J} /(\mathrm{kg} \cdot \mathrm{K})$, thermal conductivity of suspension is $0.6 \mathrm{~W} /(\mathrm{m} \cdot \mathrm{K})$.

\section{2. Procedure for obtaining a parametric field of the} turbulent flow of drilling mud

To obtain the parametric fields of pressure, vorticity, turbulent time scale, the scale of turbulence of drilling mud in the power section of SDM, we used the module Flow Simulation from the programming environment SolidWorks (SOLIDWORKS Flow Simulation and Darin Grosser, 2011) [12, 13].

To control the stator surface of the screw motor and to photograph the damage, we applied an endoscope for pipes.

\section{Results of examining the turbulent flow of drilling mud in the working space of SDM power section}

For modeling, we built a 3D model of the working pair of the screw down-hole motor manufactured by Wenzel Downhole Tools when drilling at the Gnidintsy oil and gas condensate field (belongs to the Glinsko-Solokhiv gas-oil region of the Eastern oil and gas region of Ukraine).

We set the following boundary conditions for the study: initial temperature of the drilling mud is $30{ }^{\circ} \mathrm{C}$, pressure at the inlet to the working pair of SDM is $24 \mathrm{MPa}$, volumetric flow rate of drilling mud is $0.027 \mathrm{~m}^{3} / \mathrm{s}$ (Fig. 2).

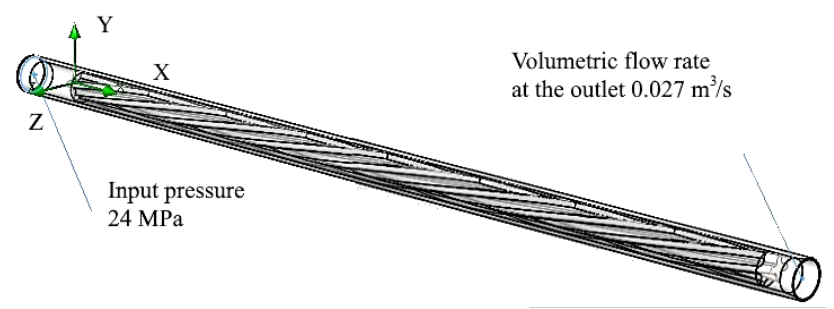

Fig. 2. Boundary conditions for modeling a working pair of the screw down-hole motor
By using the module Flow Simulation from the programming environment SolidWorks, we derived the models of parametric fields of pressure, vorticity, turbulent time scale, and the scale of turbulence at the surfaces of the rotor and the stator.

Fig. 3, $a$ shows the resulting models of the pressure field of drilling mud in the power section of a screw downhole motor, specifically at the internal surface of the stator (Fig. 3, $a$ ) and the rotor (Fig. 3, b).

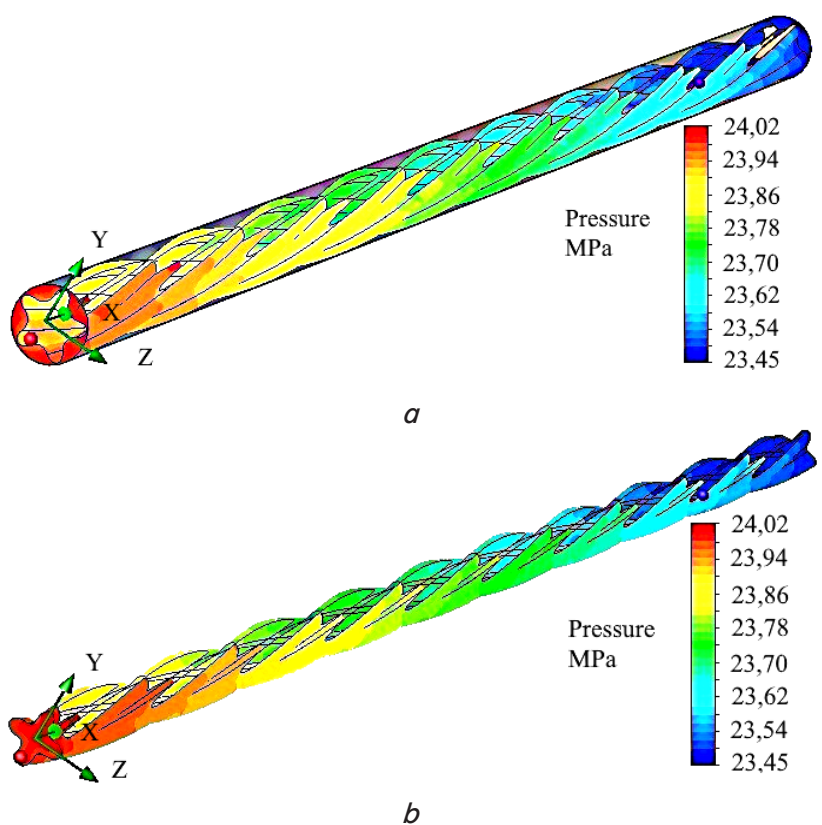

Fig. 3. Model of the pressure field of drilling mud in the power section of SDM: $a-$ at the stator surface; $b-$ at the rotor surface

We observe a decrease in the pressure from maximum value $(24.02 \mathrm{MPa})$ at the inlet to the power section to minimum value $(23.45 \mathrm{MPa})$ at the outlet.

Fig. 4 shows the models of vorticity field of drilling mud at the surface of the stator (Fig. 4, $a$ ) and the rotor (Fig. 4, $b$ ).

As indicated by these models, the value of vorticity ranges from $0 \mathrm{~s}^{-1}$ (in places of contact between the stator and the rotor) to $1,876 \mathrm{~s}^{-1}$ (in the vicinity of screw slots and stator projections).

Fig. 5 shows models of the turbulent time scale field of drilling mud in the power section of SDM.

The model derived clearly shows at the surface of the stator (Fig. 5, $a$ ) and the rotor (Fig. 5, $b$ ) noticeable maximum values (to $4.026 \mathrm{~s}$ ) observed in the cavities formed between the teeth of the rotor and the stator in the region opposite to the rotor rotation direction.

Fig. 6 shows the obtained models of the turbulence scale field of drilling mud in the power section of SDM.

It should be stated that the maximum value of a given parameter at the surface of the stator (Fig. 6, $a$ ) and the rotor (Fig. 6, b) is $5.666 \mathrm{~mm}$, and the minimum value is $0.011 \mathrm{~mm}$.

Fig. 7 shows endoscopic images of damage in the rubber coating of SDM stators, which were used while opening Ostroverkhov gas condensate field (Kharkiv oblast, close to the town of Merefa. The deposit is located on the northern board at the south-eastern part of Dnieper-Donetsk basin) and Sakhalin oil and gas condensate field (Kharkiv oblast, close to the town of Krasnokutsk). It is localized in the cen- 
tral part of the northern near-board area of Dnieper-Donetsk basin, it belongs to the Talalayevsko-Ribalsky oil and gas area of the Eastern oil and gas region of Ukraine.

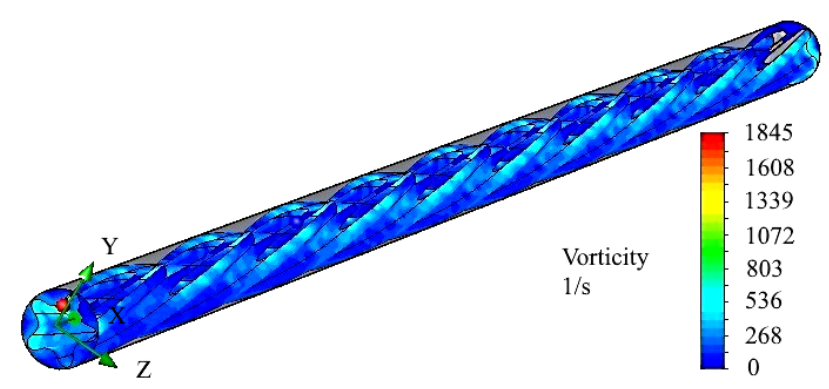

$a$

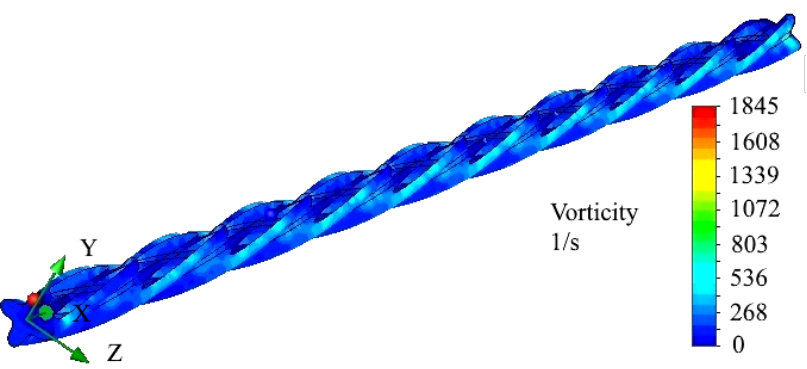

$b$

Fig. 4. Vorticity field model of drilling mud in the power section of SDM: $a-$ at the surface of the stator;

$b-$ at the surface of the rotor

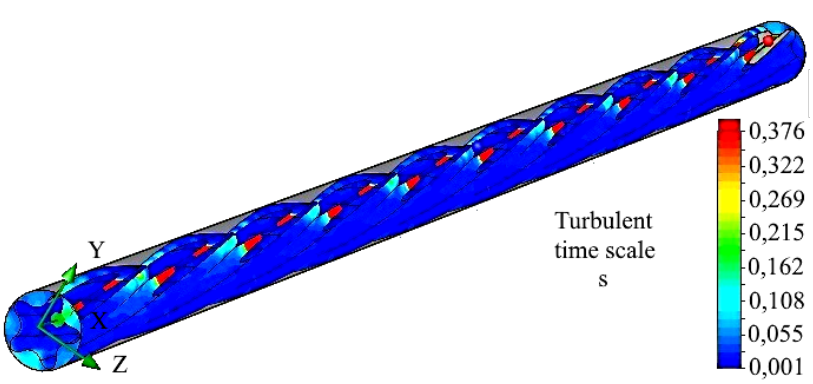

$a$

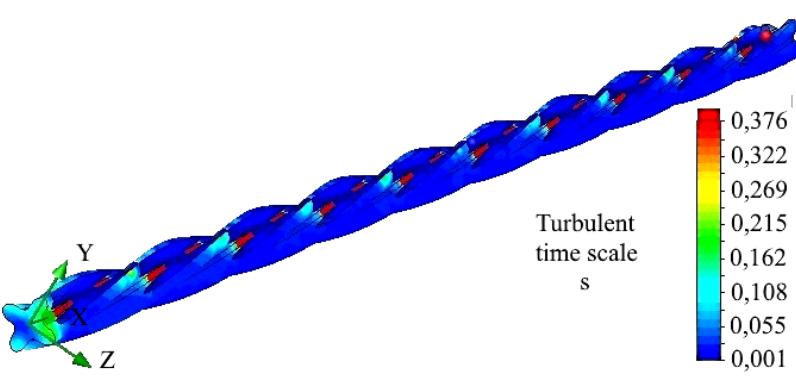

$b$

Fig. 5. Turbulent time scale field model of drilling mud in the power section of SDM: $a-$ at the surface of the stator; $b-$ at the surface of the rotor

The character of damage at the surface of the stator, as shown by the analysis of images in Fig. 7, is the deep scratches, guide scratches, rarer - cavities. Localization of the damage is from the middle and to the tail part of the power section.

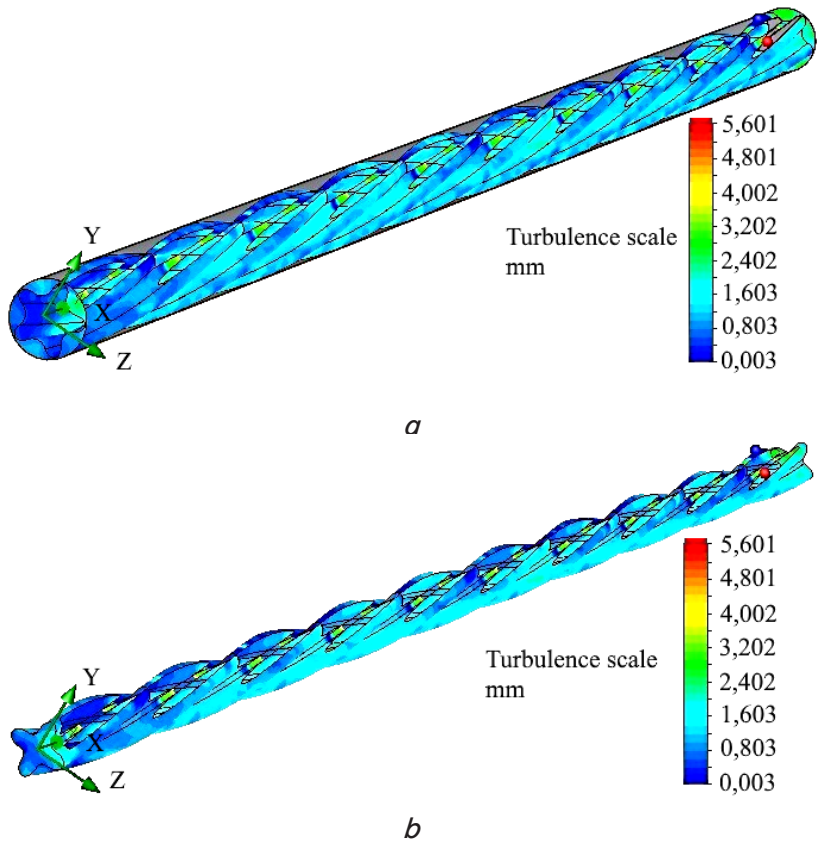

Fig. 6. Turbulence scale field model of drilling mud in the power section of SDM: $a-$ at the surface of the stator; $b-$ at the surface of the rotor

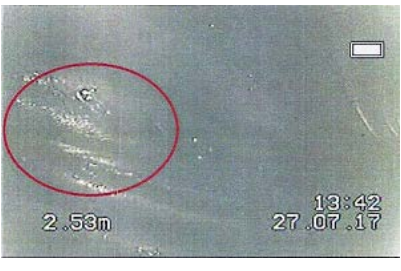

$a$

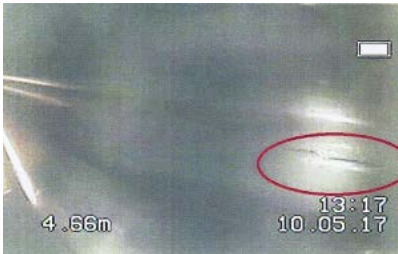

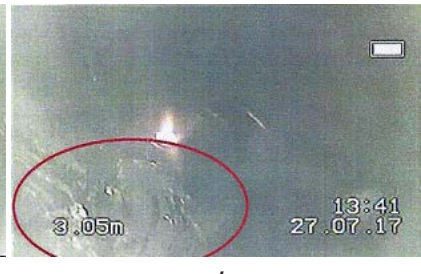

b

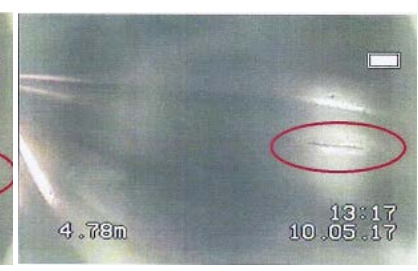

$d$
Fig. 7. Endoscopy of the SDM rotor surface. Images, taken as of 2017, show a distance of damage from the beginning of a power section (in meters): $a-$ at a distance of $2.53 \mathrm{~m}$; $b-$ at a distance of $3.05 \mathrm{~m} ; c-$ at a distance of $4.66 \mathrm{~m}$; $d-$ at a distance of $4.78 \mathrm{~m}$

\section{Discussion of results of examining the turbulent flow of drilling mud in the power section of SDM}

To conduct detailed analysis of change in the operational parameters of the working space of a SDM power section: pressure, vorticity, turbulent time scale, and the scale of turbulence of drilling mud, we constructed the charts by using the module Flow Simulation (Fig. 8). Breaks in the curve of charts coincide with the points of contact between edges of the rotor and the stator.

Based on the results of simulation, Table 1 gives possible maximum and minimum values of the examined parameters of drilling mud at the surface of the working bodies of the 
SDM power section, specifically pressure, vorticity, turbulent time scale, and the scale of turbulence.

We shall analyze the resulting model data for a change in the parametric fields of operational parameters of drilling mud in the SDM power section.

A pressure parameter. We registered a slight decrease in pressure at the outlet of the power section relative to the pressure at the inlet (from 24.02 to $23.45 \mathrm{MPa}$ ), caused by the loss of drilling mud head along the length of the SDM power section. It is noteworthy that these data are almost identical to those obtained in earlier study [11].

When the drilling mud moves, there is a planetary rotation of the rotor over the stator's teeth while at the same time maintaining a continuous contact between the rotor and the stator along the entire length. This causes the formation of cavities with high and low pressure (in which pressure decreases in a stepwise fashion - refer to Fig. 8, $a$ ), and the engine executes its working process.

A vorticity parameter. The presence in the working space of a SDM power section of the vorticity of drilling mud is the evidence that in the examined environment there are "eddies" - rotating elements of the volume. A quantitative measure of vorticity is the speed rotor [14]:

$\omega=\operatorname{rot} v$.

Thus, the turbulent movement of a drilling mud suspension in the space of a SDM power section can be represented by a vector field, which is the field of velocity of liquid environment. The rotor of this vector field at a given point is equal to the doubled vector of angular velocity of rotation of an element of the environment with the center at this point. The direction of the rotor coincides with the axis of rotation.

When the rotor rolls over the stator, the profile of cavities between the surfaces "rotor-stator" from the points of contact between the stator and the rotor to the points of maximum distance changes, which causes a change in the vorticity within $\omega=0-1,876 \mathrm{~s}^{-1}$ and in the character of curve $\omega(L)$ - refer to Fig. $8, b$. In this case, the symmetry of the rotor and stator predetermines the symmetry of profile of chambers between them along the length of the power section, which is mirrored in the symmetry (repeatability) of curve $\omega(L)$ in separate chambers between the surfaces "rotor-stator".

Table 1

Maximum and minimum values of operational parameters of drilling mud in the power section of SDM

\begin{tabular}{|c|c|c|}
\hline Parameter & Max value & Min value \\
\hline Pressure, $\mathrm{MPa}$ & 24.02 & 23.45 \\
\hline Vorticity, $\mathrm{s}^{-1}$ & 1875.7 & 0 \\
\hline Turbulent time scale, $\mathrm{s}$ & 4.026 & 0.001 \\
\hline Turbulence scale, $\mathrm{mm}$ & 5.666 & 0.011 \\
\hline
\end{tabular}

A turbulent time scale. The integrated turbulent time scale of flow characterizes correlations of turbulent pulsations over time. It can be derived as [15, 17]:

$$
T=\int_{0}^{\infty} r(t) \mathrm{d} t
$$

where $r(t)$ is the autocorrelation function of rotation speed of a turbulent flow; $t$ is the time interval.

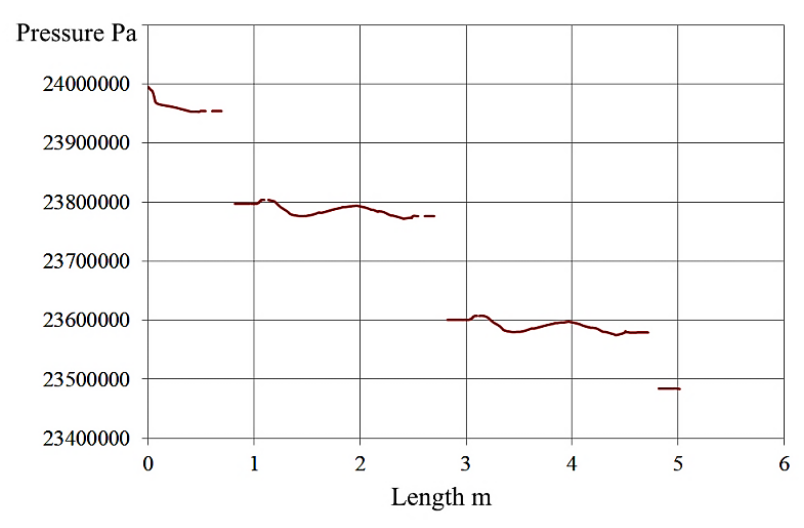

$a$
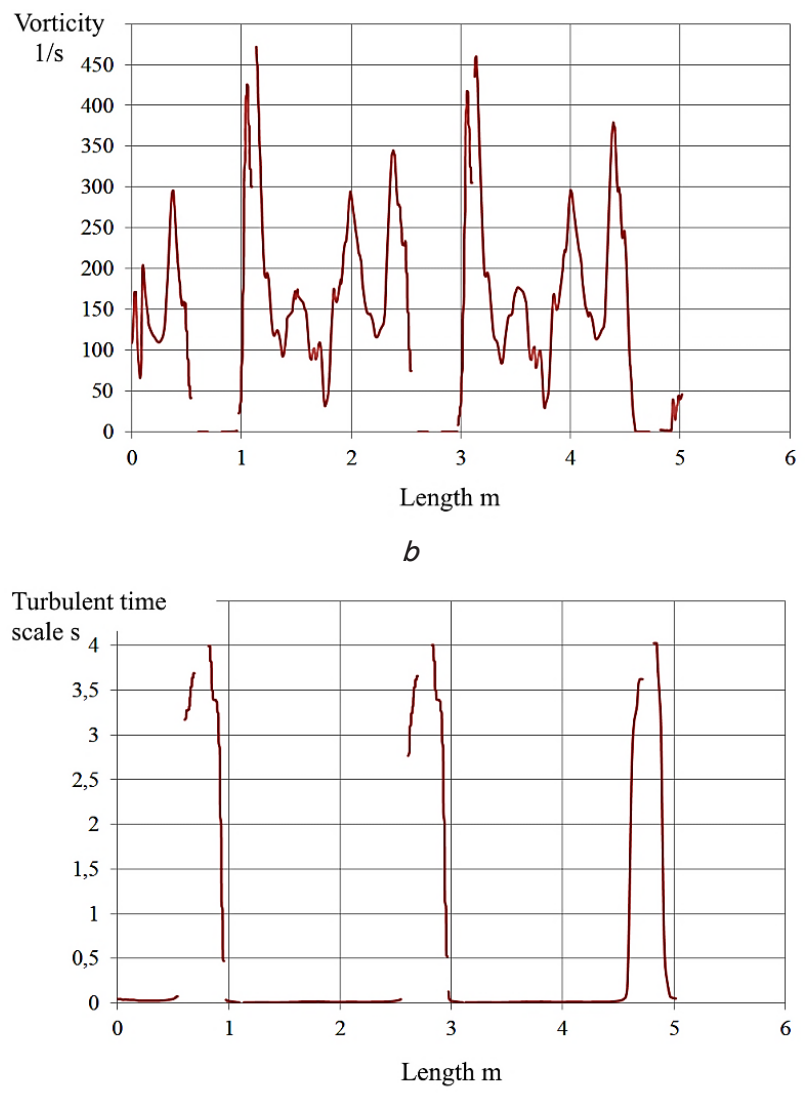

c

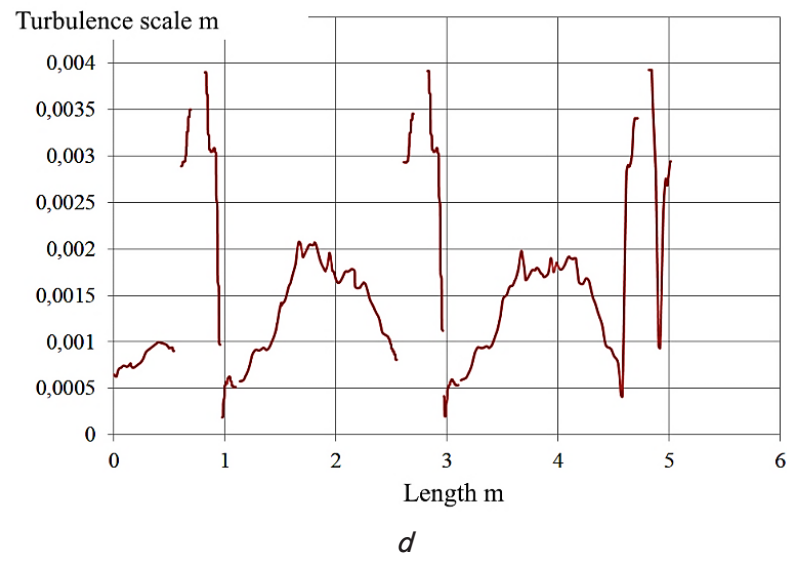

Fig. 8. Charts of change in the parameters of drilling mud calculated at the tooth edge of the rotor along length $(L)$ of the power section: $a$ - pressure; $b$ - vorticity; $c$ - turbulent time scale; $d-$ metric scale of turbulence 
Thus, the integrated turbulent time scale of the flow is quantitatively estimated by the area under curve $r(t)$ in the range $0-\infty$ (2). If the autocorrelation function $r(t)$ quickly decreases, then the autocorrelations are mostly observed at small intervals of time $t$. This corresponds to the elevated rotation frequency of vortices; parameter $t$ is relatively small. In the opposite case, if the autocorrelation function $r(t)$ falls slowly, the autocorrelations are observed both at small and larger intervals of time $t$. This corresponds to the reduced frequencies of rotation of the vortices; parameter $T$ increases. Paper [16] highlights another trend - the interdependence of spectra of turbulent pulsations by the scale of time and linear dimensions of vortices. That is, it is argued that it is the small-scale turbulent vortices that have the small time scales (which can be associated with the frequency of rotation of these vortices). The author of [16] suggests that these vortices are statistically independent on the large- and medium-scale energy-intensive vortices. In a given study, the examined oscillations of the integrated turbulent time scale within $0.001-4,026 \mathrm{~s}$ indicate a wide range of frequencies of turbulent pulsations of drilling mud in the power section of SDM.

A metrical scale of turbulence. The integrated metrical (linear) turbulent flow scale characterizes correlations of turbulent pulsations in space. Essentially these are the twopoint correlations of flow rate. The metrical scale of turbulence can be derived, similar to (1), as [17]:

$$
L=\int_{0}^{\infty} r(t) \mathrm{d} x
$$

where $r(t)$ is the autocorrelation function of rotation speed of a turbulent flow; $x$ is the distance between two points in a flow.

Value of the integrated metrical scale of turbulent scale of the flow of drilling mud in the power section of SDM ranges from 0.011 to $5.666 \mathrm{~mm}$.

We shall focus on two specific regions - a neighborhood of points of contact between the rotor edge and the stator and in the section between these points.

Regions in the vicinity of contact points between the rotor edge and the stator are clearly pronounced anomalous zones in terms of the characteristics of turbulence. Vorticity (angular rotation speed of turbulent vortices) at this point drops to almost 0 . Turbulent time scale $T$ increases, corresponding to the reduced rotation frequencies of vortices in the neighborhood of point of contact "rotor-stator". The metrical scale of turbulence (3) increases sharply, which also indicates a degeneration of finely-dispersed turbulent pulsations. As a result, developed turbulence (secondary and tertiary vortices) almost disappears; the dissipation of flow energy significantly decreases.

In the region between the points of contact of the rotor edge and the stator there is another pattern of the drilling mud turbulence. The angular rotation speed of the turbulent vortices increases dramatically and curve $\omega(L)$ "pulses" along the section. Turbulent time scale (2) drastically reduces to a minimum value, indicating the presence of smallscale turbulent vortices characterized by the flow energy dissipation. The latter is confirmed also by low values of the integrated metrical turbulent scale. Thus, in the region between the points of contact "rotor-stator" there is the developed turbulence of drilling mud, which causes enhanced dissipation of the flow energy. These regions are the most vulnerable to a damage to the stator by a solid phase of the drilling mud, registered in the photograph from Fig. 7.

Thus, in this work, at the following boundary conditions: initial temperature of drilling mud is $30{ }^{\circ} \mathrm{C}$, pressure at the inlet of the working pair of SDM is $24 \mathrm{MPa}$, volumetric flow rate of drilling mud is $0.027 \mathrm{~m}^{3} / \mathrm{s}$, we simulated a current of drilling mud in the power section of the screw down-hole motor manufactured by Wenzel Downhole Tools (Canada) with a diameter of $171 \mathrm{~mm}$. Drilling mud parameters: density is $1,100 \mathrm{~kg} / \mathrm{m}^{3}$, dynamic viscosity is $0.02 \mathrm{~Pa} \cdot \mathrm{s}$, specific heat capacity is $4.2 \mathrm{~J} /(\mathrm{kg} \cdot \mathrm{K})$, thermal conductivity of suspension is $0.6 \mathrm{~W} /(\mathrm{m} \cdot \mathrm{K})$. The maximum and minimum values of operational parameters of drilling mud registered in the power section of SDM are given in Table 1.

A change in these parameters would probably alter the quantitative characteristics of the drilling mud current, specifically vorticity, turbulent time scales and metrical turbulent scales. In this case, however, the patterns observed (Fig. 8) will remain unchanged.

Prospects for the continuation of study into the process of turbulent flow of drilling mud in the working space of power section of the screw down-hole motor and the relationships between its parameters and damages to the working surface of the SDM stator imply, first, a theoretical analysis of the dependence of Reynolds stress tensor with the averaged parameters of the drilling mud flow, applying the known models of turbulence: $k-\varepsilon$ and $k-\omega$ models (here $k$ is the turbulent kinetic energy, $\varepsilon$ is the dissipation rate of turbulence energy, $\omega$ is the specific dissipation rate of turbulence energy) [18].

In addition, further research would address a regression analysis of frequency and distribution, along the length of the power section of SDM, of damage to the rotor, depending on the parameters of drilling mud (density, viscosity, etc.), current of the flow (rate) and turbulence parameters (Re number, intensity of turbulence, vorticity, scale of turbulence).

\section{Conclusions}

1. An analysis of the obtained model parametric fields of turbulent flow of drilling mud in the power section of SDM shows two distinctive regions that differ by the characteristics of turbulence in drilling mud current. These sections are localized in the neighborhood of contact points "rotor-stator", and along the distance between these points. In the first section, the developed flow turbulence almost disappears; the dissipation of flow energy significantly decreases. In the second section, there is a developed turbulence of drilling mud. Vorticity of drilling mud in this region reaches the maximum values of $1,875.7 \mathrm{~s}^{-1}$. Turbulent time scale in the second region reaches the minimum values of $0.001 \mathrm{~s}$, and the metrical scale of pulsations is comparatively small - from 0.011 to $5.666 \mathrm{~m}$, indicating the presence of small-scale turbulent vortices and the elevated dissipation of flow energy. Thus, the second section is the most vulnerable to a damage to the stator by a solid phase of drilling mud.

2. An endoscopic examination of the surface of the stator of SDM, which we conducted, revealed damage to its working surface, specifically deep scratches, guide scratches, 
cavities. Localization of damage is from the middle and to the tail part of the power section. The damage is registered at a distance of $2.53-4.78 \mathrm{~m}$ from the beginning of the power section of SDM.

The obtained data on SDM models could be used in hydraulic calculations of the screw down-hole motor, for choosing a rational mode of its operation.

\section{Acknowledgement}

Authors express their gratitude to the Ukrainian company TOV "NTP Burova Tekhnika" for providing information on the initial parameters of SDM, practical experience, and, in particular, for allowing us to get acquainted with actual operation of SDM at the Gnidintsy field (Ukraine).

\section{References}

1. Issledovanie raboty pary «elastomer - metall» silovoy sekcii vintovogo zaboynogo dvigatelya / Ismakov R., Zakirov N., Al-Suhili M., Toropov E. // Sovremennye problemy nauki i obrazovaniya. 2015. Issue 2.

2. K voprosu prodleniya sroka sluzhby vintovyh zaboynyh dvigateley / Ovchinnikov V. P., Dvoynikov M. V., Bud'ko A. V., Prolubshchikov S. V. // Burenie i neft'. 2007. Issue 10. P. 40-46.

3. Vintovye zaboynye dvigateli firmy «Radius-Servis» / Andoskin V. N., Vyguzov A. M., Kuznecov A. V., Hayrullin D. N., Novikov R. S. // Burenie i neft'. 2014. Issue 11. P. 50-53.

4. Positive Displacement Motor Modeling: Skyrocketing the Way We Design, Select, and Operate Mud Motors / Ba S., Pushkarev M., Kolyshkin A., Song L., Yin L. L. // Abu Dhabi International Petroleum Exhibition \& Conference. 2016. doi: 10.2118/183298-ms

5. Syzrantseva K., Syzrantsev V. Load on Multipair Contact Zones of Operating Parts of Screw Pumps and Motors: A Computer Analysis // Procedia Engineering. 2016. Vol. 150. P. 768-774. doi: 10.1016/j.proeng.2016.07.104

6. Failure Analysis of the Rotor of Downhole Drilling Motors / Weng W., Yue W., Shi X., Huang Y. // ICPTT 2013. 2013. doi: $10.1061 / 9780784413142.089$

7. Experimental research of drilling mud influence on mud motor mechanical rubber components / Epikhin A. V., Ushakov A. V., Barztaikin V. V., Melnikov V. V., Ulyanova S. // IOP Conference Series: Earth and Environmental Science. 2015. Vol. 27. P. 012051. doi: 10.1088/1755-1315/27/1/012051

8. Ismakov R., Al-Suhili M. Issledovanie vliyaniy razlichnyih reagentov na rabotu silovoy sektsii vintovyih zaboynyih dvigateley // Elektronnyy nauchnyy zhurnal «Neftegazovoe delo». 2015. Issue 1. P. 64-78.

9. Sazonov I. A., Mokhov M. A., Demidova A. A. Development of Small Hydraulic Downhole Motors for Well Drilling Applications // American Journal of Applied Sciences. 2016. Vol. 13, Issue 10. P. 1053-1059. doi: 10.3844/ajassp.2016.1053.1059

10. Delpassand M. S. Stator Life of a Positive Displacement Downhole Drilling Motor // Journal of Energy Resources Technology. 1999. Vol. 121, Issue 2. P. 110. doi: 10.1115/1.2795065

11. Biletskyi V., Landar S., Mishchuk,Y. Modeling of the power section of downhole screw motors // Mining of Mineral Deposits. 2017. Vol. 11, Issue 3. P. 15-22. doi: 10.15407/mining11.03.015

12. SOLIDWORKS Flow Simulation. URL: http://www.solidworks.com/sw/products/simulation/flow-simulation.htm

13. The Future of SolidWorks Has 'Always' Been in Your Hands. URL: http://blog.dasisolutions.com/2011/09/27/the-future-of-solidworks-has-always-been-in-your-hands/

14. Ludwig B., Clemens S. Lehrbuch der Experimental-physik // Band 1: Mechanik, Relativität, Wärme. Berlin, 1998.

15. Handbook of Turbulence. Vol. 1 / W. Frost, T. H. Moulden (Eds.) // Fundamentals and Applications. Springer, 1977. doi: $10.1007 / 978-1-4684-2322-8$

16. Kurbackiy A. F. Vvedenie v turbulentnost'. Novosibirsk, 2000. 118 p.

17. Autocorrelation Functions and the Determination of Integral Length with Reference to Experimental and Numerical Data / O’Neill P. L., Nicolaides D., Honnery D., Soria J. // 15th Australasian Fluid Mechanics Conference. 2004. URL: https://www. researchgate.net/publication/253210572_Autocorrelation_Functions_and_the_Determination_of_Integral_Length_with_Reference_to_Experimental_and_Numerical_Data

18. Monin A. S., Yaglom A. M. Statistical hydromechanics: the theory of turbulence. Moscow: Science. Ch. Ed. fiz.-mat. lit., 1992.695 p. 